\title{
Role of oxidative stress in opiate withdrawal and dependence: Exploring the potential use of honey
}

\author{
Nor Hidayah Abu Bakar ${ }^{*}$, Siti Norhajah Hashim, Nasir Mohamad, Rohayah Husain, Liyana Hazwani Mohd Adnan, \\ Halim Shariff, Nur Husna Zakaria \\ Opioid Research Interest Group, Faculty of Medicine, Universiti Sultan Zainal Abidin (UniSZA), Medical Campus, Jalan Sultan Mahmud, 20400 Kuala \\ Terengganu, Terengganu, Malaysia.
}

\begin{tabular}{|c|c|}
\hline ARTICLE INFO & ABSTRACT \\
\hline Article history: & \multirow{7}{*}{$\begin{array}{l}\text { Opiate dependence and withdrawal is a worldwide public health problem and give a significant burden to society. } \\
\text { In exploring the problems of opiate dependence and withdrawal, oxidative stress in thought to be involved in the } \\
\text { mechanism of the development of dependence and tolerance to morphine. Therefore, there is possibility that } \\
\text { antioxidant has the role to reduce the oxidative stress leading to opiate dependence and withdrawal. In this mini } \\
\text { review we describe the evidence of relationship between oxidative stress and opiate dependence. We also } \\
\text { describe the evidence of honey which has been claimed to have high antioxidant properties and its promising } \\
\text { potential to reduce oxidative stress in opiates dependence and tolerance individuals. }\end{array}$} \\
\hline Received on: 20/08/2015 & \\
\hline Revised on: 19/09/2015 & \\
\hline Accepted on: 02/10/2015 & \\
\hline Available online: $27 / 12 / 2015$ & \\
\hline Key words: & \\
\hline $\begin{array}{l}\text { Opiate dependence and } \\
\text { withdrawal, antioxidant, } \\
\text { oxidative stress, honey. }\end{array}$ & \\
\hline
\end{tabular}

\section{INTRODUCTION}

In Malaysia, opiates dependence implicates the country's social and economic development. Harm Reduction Programme was initiated by Malaysia Ministry of Health in 2006, in which Methadone Maintenance Therapy was introduced to be used as a therapeutic method in controlling opioid dependence problems. However, the used of methadone itself would cause dependence and its therapeutic dose had to be increased over the period of time to get the same results (Mattick et al., 2009).Various methods had been used to attenuate opiate dependence including the use of non-addictive materials. These included the use of natural food and plants such as ginger, Habbatu sauda, herb roots and many more (Tu et al., 2015; Darvishzadeh-Mahani et al., 2012; Abdel-Zaher et al., 2010). Honey is a natural food produced by bees which provides a lot of benefits to mankind as honey has been used for medicine and as food supplements. Honey bees have been identified to possess

\footnotetext{
* Corresponding Author

Nor Hidayah Abu Bakar, Opioid Research Interest Group, Faculty of Medicine, Universiti Sultan Zainal Abidin (UniSZA), Medical Campus, Jalan Sultan Mahmud, 20400 Kuala Terengganu, Terengganu, Malaysia. Email:norhidayahabubakar@yahoo.com
}

many medicinal values such as anti-cancer; burn wound healing, antibacterial and it also has positive effects on the brain such as to improve memory. This is attributed to the bioactive compounds in honey such as flavonoids and phenolics (Othman et al., 2015; Jaganathan et al., 2014; Alzahrani et al., 2012; Alvarez-Suarez et al., 2012; Al-Waili et al., 2011; Krystyna and Magdalena, 2009; Isabel et al., 2009; Khan et al., 2007).

\section{ROLE OF OXIDATIVE STRESS ON THE MECHANISM OF OPIATE WITHDRAWAL AND DEPENDENCE}

Opiate dependence is defined as the need to take opioid at regular interval to avoid withdrawal syndrome. It occurs because of the changes in the brain system especially in the locus coeruleus at the base of the brain. The absence of exogenous opioids will stimulate the locus coeruleus brain cells to release excessive amounts of noradrenaline triggering jittery, anxiety, muscle cramps and diarrhea, increased heart rate, increased blood pressure, widening of pupils and widening of air passages in the lungs as well as narrowing of the blood vessels in non-essential organs. On the other hand, when opiate molecule binds to $\mu$ receptors on the brain cells in locus coeruleus, it suppresses the release of noradrenaline resulting in drowsiness, slow respiratory rate and low blood pressure (Kosten and George, 2002). 
There are two mechanisms involved in the development of oxidative stress; formation of free radicals and reduction of antioxidant activity (Mori et al., 2007). The neurotransmitter and gasotransmitters involved in these mechanisms are predominantly glutamate and nitric oxide. Opiate intake affects the mechanism of oxidative stress in the brain. This had been proposed by previous studies which indicated that oxidative stress causes opiate dependency (Mannelli et al., 2009; Abdul Zaher et al., 2013).

It was found that morphine increased the lipid peroxidation in tissues whereas heroin led to oxidative DNA damage, protein oxidation and lipid peroxidation in the brain of mice (Ozmen et al., 2007; Qiusheng et al., 2005). Opioid drugs also exerts effect on the activity of antioxidant systems, as observed by decrease in the total antioxidant capacity in the blood of human heroin addict when compared to the control groups (Pereska et al., 2007). In the experiment with mice exposed to heroin, there was a decrease in the activity of antioxidant enzymes in the brain such as superoxide dismutase (SOD), catalase and glutathione peroxidase (GPx). Other than that, the ratio of glutathione (GSH) to oxidized glutathione (GSSG) was also decreased, leading to reduction in learning ability of the mice (Guzman et al., 2006). In other studies, Pan et al., (2005) noted a reduction in total antioxidant capacity in the serum and in the antioxidant enzymes, such as SOD, catalase, GPx and elevated markers of oxidative damage of DNA, proteins and lipids in heroin induced mice (Xu et al., 2006). This proposed mechanism was further supported by evidence that pre-treatment with free radical scavengers reducing the symptom of morphine withdrawal syndrome in mice (Abdel-Zaher et al., 2013; DarvishzadehMahani et al., 2012; Abdel-Zaher et al., 2011, Abdel-Zaher et al., 2010). Abdel-Zaher et al. (2013) also reported the possible role of oxidative stress and nitric oxide (NO) synthase isoforms in the development of morphine tolerance and dependence, and the effect of alpha-lipoic acid (LA) on these parameters were investigated in mice. They suggested that alpha-LA inhibited morphine-induced oxidative stress and increase the activity of inducible NO synthase in the brain which can attenuate the development of morphine tolerance and dependence. Response to inhibition of morphineinduced NO overproduction and oxidative stress to ameliorate opioid tolerance and dependence was also noted in a study using nigella sativa oil (Abdel-Zaher et al., 2010). Other studies also reported that reduction in oxidative stress will attenuate the development of morphine tolerance and dependence. The studies were done by using thymoquinone for the treatment. Repeated administration of thymoquinone along with morphine attenuated the development of morphine tolerance and dependence, as measured by the hot plate test and assessed by naloxoneprecipitated withdrawal manifestations respectively (Abdel-Zaher et al., 2013).

\section{ANTIOXIDANT PROPERTIES OF HONEY}

Antioxidant properties of honey are responsible to give balance to a number of antioxidants and free radicals in the body
(Bogdanov, 2010; Bogdanov et al., 2008). Abdel-Zaher et al. (2010) reported that reduction in oxidative stress in opiate addicts will reduce dependence and withdrawal symptoms. Looking into this mechanism, honey therefore has a promising effect on the inhibition of morphine-induced oxidative stress which is responsible for the problems of dependence and tolerance in opiate addiction individuals.

Many chronic diseases are linked to the increased oxidative stress caused by an imbalance between liberal-radical production and the antioxidant level. Antioxidants, which are abundant in natural honey, are free-radical scavengers that reduce the formation of or neutralize free radicals (Isnandia Andrea et al., 2013; Letícia et al., 2008). Antioxidant properties of honey had been explored both in in-vitro and in-vivo studies, in which the authors found that the antioxidant attributes of honey reduced cell damage induced by oxidative stress (Erejuwa et al., 2012).

Diabetes is known as one of the chronic diseases due to oxidative stress. Honey has been used traditionally to treat diabetes. Its antioxidant properties help in reducing free radicals generated as a consequence of the disease process that will ameliorate the patient's general health status. Both studies done using gelam honey and flavonoids showed that the number of reactive oxygen species (ROS) in diabetic induced cell culture decreased and resulted in higher number of living cells. Comparison study on the effects of pure gelam honey and flovonoid on diabetic-induced cell culture resulted in better outcome from the former (Batumalaie et al., 2014; Batumalaie et al., 2013).

The antioxidant content in honey varies depending on its geographical origin (Bogdanov, 2010; Bogdanov et al., 2008). This is because different geographical areas have different types of flowers as the sources of honey production. Honey produced from flowers such as lavender, wild carrot, Manuka and Acasia have been shown to have high antioxidant activity (Alzahrani et al., 2012).

Based on the antioxidant properties, honey therefore can be used as food supplement to improve general health of the body. Studies done by Goon et al. (2014) as well as June and Megan, (2012) reported a reduction in DNA damage and antioxidant enzyme activity with the use of honey.

\section{CONCLUSIONS}

Chronic used of opiates will cause imbalance between oxidants and antioxidants due to an increase of morphine-induced oxidative stress that leads to the development of dependence and tolerance.

Honey which is claimed to have high antioxidant properties probably has a potential to reduce oxidative stress in opiates dependence and tolerance individuals. This promising potential is therefore becoming the focus of interest in our current study in opioid dependence and withdrawal in order to look deeper into the mechanism and in finding the complementary supplements 
of the therapy for the better treatment outcome in opioid dependence and withdrawal.

\section{ACKNOWLEDGEMENT}

Authors are thankful to NRGS/2013 grant number RR057-1 from Malaysia Ministry of higher education.

\section{REFERENCES}

Abdel-Zaher AO, Abdel-Rahman MS, and FM EL. Blockade of nitric oxide overproduction and oxidative stress by Nigella sativa oil attenuates morphine-induced tolerance and dependence in mice. Neurochem Res, 2010; 35 (10) : 1557-1565.

Abdel-Zaher AO, Mostafa MG, Farghaly HM, Hamdy MM, and Abdel-Had RH. Role of oxidative stress and inducible nitric oxide synthase in morphine-induced tolerance and dependence in mice. Effect of alpha-lipoic acid. Behav Brain Res, 2013; 247:17-26.

Abdel-Zaher AO, Mostafa MG, Farghly HM, Hamdy MM., Omran GA, and Al-Shaibani NK. Inhibition of brain oxidative stress and inducible nitric oxide synthase expression by thymoquinone attenuates the development of morphine tolerance and dependence in mice. Eur J Pharmacol, 2013;702 (1-3): 62-70.

Akanmu MA, Olowookere TA, Atunwa SA, Ibrahim BO, Lamidi OF, Adams PA, and Adeyemo LE. Neuropharmacological effects of Nigerian honey in mice. Afr J Tradit Complement Altern Med, 2011; 8 (3): $230-249$

Alvarez-Suarez JM, Francesca G, González-Paramás AM, Elisabetta D, Paola A, Martinez-Sanchez Gregorio, Stefano B, José LQ, Santos-Buelga C. and Maurizio B. Phenolics from monofloral honeys protect human erythrocyte membranes against oxidative damage. Food and Chemical Toxicology , 2012 ; 50: 1508-1516.

Alvarez-Suarez JM, Giampieri F, andBattino M. Honey as a source of dietary antioxidants: structures, bioavailability and evidence of protective effects against human chronic diseases. Curr Med Chem, 2013; 20 (5): 621-638.

Al-Waili N, Salom K, and Al-Ghamdi AA. Honey for wound healing, ulcers, and burns; data supporting its use in clinical practice. Scientific World Journal, 2011;11:766-787.

Alzahrani HA, Alsabehi R, Boukraa L, Abdellah F, Bellik Y, andBakhotmah BA. Antibacterial and antioxidant potency of floral honeys from different botanical and geographical origins. Molecules, 2012; 17(9): 10540-10549.

Batumalaie K, Qvist R, Yusof KM, Ismail IS, andSekaran SD. The antioxidant effect of the Malaysian Gelam honey on pancreatic hamster cells cultured under hyperglycemic conditions. Clinical and Experimental Medicine, 2014; 14 (2): 185-195.

Batumalaie K, Zaman Safi S, Mohd Yusof K, Shah Ismail I, Devi Sekaran S, and Qvist R. Effect of gelam honey on the oxidative stress-induced signaling pathways in pancreatic hamster cells. Int $\mathbf{J}$ Endocrinol, 2013; 367-312.

Bogdanov S. Nutritional and functional properties of honey. VoprPitan, 2010; 79 (6): 4-13.

Bogdanov S, Jurendic T, Sieber R, and Gallmann P. Honey for nutrition and health: a review. J Am CollNutr, 2008; 27 (6): 677-689.

Darvishzadeh-Mahani F, Esmaeili-Mahani S, Komeili G, Sheibani V, and Zare L. Ginger (Zingiber officinale Roscoe) prevents the development of morphine analgesic tolerance and physical dependence in rats. J Ethnopharmacol, 2012; 141(3): 901-907.

Erejuwa OO, Sulaiman SA, andAbWahab MS. Honey: A Novel Antioxidant. Molecules, 2012; 17 (4): 4400-4423.

Goon JA, Choor CK, Ainaa RN, Sze XQ, Syahriah M, Syamimi MSN, Zakiah J. Effect of Nenas Honey Supplementation On The Oxidative Status Of Undergraduate Students. Acta Alimentaria, 2014; 43(1): 182-190.

Guzman DC, Vazquez IE, Brizuela NO, Alvarez RG, Mejia GB, Garcia EH, Isabel CFRF, Edmur A, João CMB, andLetícia, M.E.
Antioxidant activity of Portuguese honey samples: Different contributions of the entire honey and phenolic extract. Food Chemistry, 2009; 114: $1438-1443$.

Isnandia Andrea AS, Tania Maria SS, Celso AC, Neide Q, Marciane M, Jailson SN, LuizEdmundo BS, Edeltrudes OL, Antonia LS, Antonio GS, Andrea AS, Tania Maria SS, Celso AC, Neide Q, Marciane M, Jailson SN, LuizEdmundo BS, Edeltrudes OL, Antonia Lucia S, Antonio Gouveia $\mathrm{S}()$. Phenolic profile, antioxidant activity and palynological analysis of stingless bee honey from Amazonas, Northern Brazil. Food Chemistry, 2013; 141: 3552-3558.

Jaganathan SK, Balaji A, Vellayappan MV, Asokan MK, Subramanian AP, John A, Marvibaigi M. A review on antiproliferative and apoptotic activities of natural honey. Anticancer Agents Med Chem, 2014;15(1): 48-56.

June CS, and Megan JB. Physicochemical properties, antioxidant activity and cellular protective effects of honeys from southern Africa. Food Chemistry, 2012; 133:1544-1550.

Khan FR, UlAbadin Z, andRauf N. Honey: nutritional and medicinal value. Int J Clin Pract, 2007; 61(10): 1705-1707.

Kosten TR, George TP. The neurobiology if opioid dependence: Implications for treatment. Sci Pract Perspect. 2002; 1: 12-20.

Krystyna $\mathrm{P}$ and Magdalena B. Analysis of phenolic acids and flavonoids in honey. Trends in Analytical Chemistry,2009;28(7).

Letícia E, Ana PP, Leandro M, Luís GD, andErmelinda P (). Antioxidant and antimicrobial effects of phenolic compounds extracts of Northeast Portugal honey. Food and Chemical Toxicology, 2008; 46: 3774-3779.

Mannelli P, Patkar A, Rozen S, Matson W, Krishnan R, andKaddurah-Daouk R .Opioid use affects antioxidant activity and purine metabolism: preliminary results. Hum Psychopharmacol, 2009; 24(8):666675.

Mattick RP, Breen C, Kimber J, andDavoli M. Methadone maintenance therapy versus no opioid replacement therapy for opioid dependence. Cochrane Database Syst Rev, 2009; 3.

Othman Z, Zakaria R, Hussain N, Hassan A, Shafin N, Ahmad A. Potential Role of Honey in Learning and Memory. Medical Sciences, $2015 ; 3(2): 3$.

Ozmen I, NazirogluM,Alici HA, Sahin F, Cengiz M, andEren I. Spinal morphine administration reduces the fatty acid contents in spinal cord and brain by increasing oxidative stress. Neurochem. Res., 2007; 32(1):19-25

Pan J, Zhang Q, Zhang Y, Ouyang Z, Zheng Q, and Zheng R. Oxidative stress in heroin administered mice and natural antioxidants protection. Life Sci., 2005; 77(2): 183-193.

Pereska Z, Dejanova B, Bozinovska C, andPetkovska L. Prooxidative/antioxidative homeostasis in heroin addiction and detoxification. Bratisl. Lek Listy, 2007; 108(9): 393-398.

Qiusheng Z, Yuntao Z, Rongliang Z, Dean G, andChangling L. Effects of verbascoside and luteolin on oxidative damage in brain of heroin treated mice. Pharmazie, 2005; 60(7): 539-543.

Santamaria D, Apreza, MR, Olguin HJ. Assessment of oxidative damage induced by acute doses of morphine sulfate in postnatal and adult rat brain. Neurochem. Res., 2006; 31(4):549-554.

Tu S, Gao J, Liu J, Zhang J, Huang Y, Xu S, Liang J. Effects of Jitai Tablet, A Traditional Chinese Medicine, on Spontaneous Withdrawal Symptoms and Modulation of Dopaminergic Functions in MorphineDependent Rats. Phytotherapy Research, 2015; 29(5): 687-694.

Xu B, Wang Z, Li G, Li B, Lin H, Zheng R, Zheng Q. Heroinadministered mice involved in oxidative stress and exogenous antioxidantalleviated withdrawal syndrome. Basic Clin Pharmacol Toxicol., 2006; 99(2): 153-161.

\section{How to cite this article:}

Abu Bakar NH, Hashim SN, Mohamad N, Husain R, Adnan LHM, Shariff H, Zakaria NH. Role of oxidative stress in opiate withdrawal and dependence: Exploring the potential use of honey. $\mathrm{J}$ App Pharm Sci, 2015; 5 (12): 159-161. 